\title{
Curriculum Management and Inclusive Education Learning in Special Needs
}

\author{
Siti Auliyatus Sholawati \\ Department of Educational Management \\ Universitas Negeri Surabaya \\ Surabaya, Indonesia \\ auliyatussholawati@gmail.com
}

\begin{abstract}
This study aims to find out, explain and analyze curriculum management and learning about inclusive education in children with special needs. This study uses a case study method. Data analysis techniques use data reduction, presentation of research data, and data verification. The subject of this study were all school teachers and employees. Data collected were through observation, interviews and document analysis. The results of the study are: (1) Curriculum planning and learning of inclusive education begins with making syllabus, lesson plans, and Individual Learning Program (ILP) adapted to the obstacles of each student with special needs who will arrange the curriculum and learning process in regular class; (2) Organizing the curriculum and learning of inclusive education starts with grouping and dividing the tasks for the implementers of curriculum and learning plans, namely homeroom teacher, study teacher and special assistant teacher in charge of assisting students with special needs. (3) In its implementation children with special needs have their own sitability for learning programs and curriculum by taking into account the developmental aspects that are on them. (4) The evaluation conducted provides a review of the results of the exixting implementation assesment.
\end{abstract}

Keywords-curriculum management; learning inclusive education; children with special needs

\section{INTRODUCTION}

Based on Article 31 paragraph 1 of the 1945 Constitution and Law Number 20 of 2003 concerning the National Education System, it can be concluded that the state Indonesia provides full guarantees to children with special needs to obtain quality education services. This shows that the eeducation of special needed has the right to get the same opportunities as other (regular) children. Special needed have received educational services in Indonesia by providing them through three kinds of educational institutions, namely, Elementary Special Schools, Integrated Education, and Special Schools [1]. Special needs as an institution for the elderly, special education accommodate children kind of interference with the same. For old people accommodate children with the same kinds of interference so that there is a special school for children with visual impairments (blind), special school for children with hearing impairments (deaf), special school for children with thinking / intelligence, special school for children with physical and motoric barriers (disability), special school for children with emotional and behavioral barriers, and SLB for children with multiple barriers. Integrated education is a regular school that also accommodates children with special needs, with curriculum, teachers, teaching facilities, and the same teaching and learning activities. However, so far it has only accommodated children with visual impairments (blind), and even then, the development is not encouraging because many regular schools object to accepting children with special needs.

According to Latief [1], support from a positive environment for inclusive education is very important because without it there will be marginalization in schools and children with special needs will be eliminated from school said by the deputy director of the UNESCO office in Jakarta. The situation of inclusive education in Indonesia and Malaysia was complained of in the report's presentation, many parents did not send their children with special needs to ordinary schools for fear that they would get rejection or discrimination [1]. In implementing inclusive education, it is necessary to addapt the needs and characteristics of students to special needs. Students with special needs in schools need modifications or adjusments, starting from the curriculum, teaching staff, learning systems, assessment systems and facilities that aim to improve the quality of effective and efficient education in accordancee with expectations [2].

Inclusion education it self is considered special in Surabaya. The inclusion school initiated by number one in Surabaya was like a fresh breeze amid the arid desert. How not, schools that accommodate students from Special Needs Children are considered better in the development of child psychology [1] compared to special schools which specifically exclude students. Mixing Children with Special Needs with other normal children in school, especially in the teaching and learning process clearly has a positive impact on the development of the psychology of children with special needs themselves. Other than that according to Bernas [3], these children are guided by specially trained teachers to facilitate them in receiving lessons.

In addition, there are also those who discuss the results of the amount of inclusion education that has been recorded. Reference [3] revealed that there were 50 elementary schools and 20 junior high schools included in the list of acceptance of new students 2017 inclusion program schools. This amount is in each sub-district. Each sub-district is made evenly because 
it is intended to facilitate access and learning rights for children with special needs. Although it looks easy, not all children are able to register as special needed students. There are several requirements that must be completed. In this regard, in the implementation of inclusive education, the principal as a leader in an educational organization has a very important role in regulating the planning, organization, implementation and control of the efforts of members of the organization and the use of other organizational resources in order to achieve the expected goals of inclusive education.

Inclusive schools are still synonymous with mixing children with special needs with ordinary children until now. Even though schools can be called inclusion, if we can see children individually with an individual approach, not classical [4]. Today, our education is seeing students with carefully and efficiently, all children are the same. And every child was born by its nature each. This means that every child must be given space and the right to develop in accordance with the capacity and talents he carries. Inclusive schools can be in line with multiple intelligence approaches.

From the developed approach, it is expected that many inclusion schools will grow without having to be burdened with all their definitions. The definition of inclusive school itself is a principle of equality of human rights, and also the answer to our differences as human beings [5]. In fact there are no humans who are the same, because all citizens have equal rights to education, including those with special needs [6]. About children with special needs is one of the core listed in the 1945 Constitution article 31. In Surabaya, there are already several schools that implement inclusion systems, of course, support from all parties is needed to develop them more optimally as an effort to provide solutions to the problem of education in Indonesia, especially at SDN Kalirungkut 1 Surabaya.

Based on the problems described in the background above, it is interesting to study. Therefore this research is interesting to do at SDN Kalirungkut 1Surabaya, to describe how curriculum management and learning of inclusive education for children with special needs in the school. the aim is to describe; (1) Planning, (2) Organizing, (3) Implementation, and (4) Curriculum evaluation and learning of inclusive education in children with special needs.

\section{METHOD}

\section{A. Research Methods}

This research uses descriptive qualitative research method which aims to be able find out and explain clearly and in detail about curriculum management and learning of inclusive education in children with special needs. Furthermore Qualitative research has two main objectives, namely first to describe and reveal (to describe and explore); the second describes and explains (to decribe and explain). In other words qualitative research does not examine a vacant land but it digs it up [7]. The results of this study are in the form of a general description of the problems studied that can only be done in a one study.
Because the approach provides the possibility to describe through careful observation, interviews with key informants in depth, so that the linkages of the aspects studied can be clearly described. With this approach, it is intended to reveal descriptive data from informants both oral and written about what they do, feel, and experience with the focus of the research [8]. In this study the data is collected under reasonable conditions, systematic and directed work methods and can be accounted for so that it does not lose its scientific nature.

\section{B. Research Time and Location}

The location of this research was carried out at SDN Kalirungkut 1 Surabaya, East Java. This location was chosen because it was considered to be able to represent several elementary schools, which included inclusive education for children with special needs. This research was conducted for approximately 3 months in April to June 2019

\section{Research Subjects}

Research informants are related to the determination of the subject of qualitative research, there are five types of sample selection in qualitative research. The selection of samples is based on simple selection criteria, comprehensive selection, queta selection, network selection and comparison selection between symptoms. Determination of samples based on these criteria is intended so that the results of the study have a value of compatibility. The subjects of this study were all staff and academic community of Surabaya's Kalirungkut-1 Elementary School, namely Principals, Deputy Principals, Students, Curriculum Offices, special companion teacher coordinators, School Committees, Special Companion Teachers, Homeroom Teachers, Regular Students, and Inclusive Students.

\section{Focus of Research}

This research This research will focus on the following: 1) Planning, 2) Organizing, 3) Implementation and 4) Evaluating the learning of inclusive education in children with special needs.

\section{E. Data Collection Techniques and Instruments}

Documentation is a data collection technique that uses records of events that have passed in the form of writing, pictures, notes, photos, videos and artwork from someone. The data collection technique aims as secondary data to obtain data that fits the research needs. The data is like pictures, photos, work culture documents, or other documents that can be used as evidence that researchers have actually conducted research on the implementation of curriculum management and learning in schools that provide inclusive education to children with special needs at the elementary level, precisely located at SDN Kalirungkut-1 Surabaya.

Interviews are data collection techniques that use question and answer through meetings of two or more people to exchange information and ideas, so that meaning can be constructed in a particular topic. In this study using unstructured interviews to obtain more in-depth data. In addition, the researcher also made interview guidelines in general, adjusted for what was asked. In addition to recording 
the process of the interview that took place, researchers will also use a tool to record so that researchers can more easily digest the results of the research.

Observation is the basis of all science. The object of research in qualitative research observed by Spredley is commonly called a social situation, which consists of three components, namely place, actor and activity. This technique is used by researchers because it is used as a way to get information and information about the situation by looking directly at what happened at the research site. In making observations, the perceptions of the researcher must be based on what has been obtained from the research subject, which is related to the learning process carried out by special assistent teacher in inclusive classes and the implementation of an adaptive curriculum at the school where research is located at SDN Kalirungkut-1 Surabaya.

\section{F. Data Analysis Techniques}

In qualitative research, data collection and analysis is carried out during simultaneous research while collecting and analyzing data after completion of data collection in a certain period. Miles and Huberman [9] stated that activities in qualitative data analysis are carried out interactively and take place continuously until complete, so that the data is saturated. In analyzing the data can be detailed in several parts, namely describing, compiling and selecting various data obtained. Furthermore, the steps used are: 1) Data reduction, 2) Presentation of research data, 3) Verification of data or conclusions of research results.

\section{RESULTS AND DISCUSSION}

SDN Kalirungkut-1 Surabaya is a school based on inclusive education in it in accordance with the decree of the head of the latest Surabaya City Education Office Number 155/0107 which was stipulated on January 2, 2018 that the number of inclusive schools in Surabaya is 55 schools. In SDN Kalirungkut-1 Surabaya, there are approximately ninety special needs students who study in regular classes with various types of disabilities. The school's vision and mission is changed every year, the goal is to further enhance the professionalism of students. The school's vision is to shape human beings who are superior, faithful, devoted, noble, master science and technology and environmentally friendly.

In its planning, inclusion learning includes several things, namely: a) syllabus planning, b) learning program planning (RPP), c) individual learning program planning that is tailored to the needs of each student. In addition the learning was also modified and selected according to its grade, namely: first, children with average academic abilities and above the high level integrated curriculum with a normal curriculum were prepared. Second, children with moderate academic ability (below average), prepared functional modification curcums. And thirdly, children with very low academic abilities are prepared for self-development development curriculum. Learning planning is planned from the beginning of the new school year by being discussed with a special team of accompanying teachers and homeroom teachers. Before making the learning plan, it is first seen from the identification of students and the assessment results that have been conducted during the previous semester. Whereas new students who plan their learning are adjusted from IQ results and initial identification when first observing acceptance of new students.

The organization of learning in inclusive education is carried out by giving authority to staff and teachers who serve as special assistant teachers and homeroom teachers. In addition, the principal also divided the tasks according to their respective sections by sorting out each division's needs for inclusive education. In practice, students remain in the regular class following the same learning as students in general, but at certain hours students with special needs are put into the source class to get additional guidance. The material given to students is not much different from students in general, while using the 2013 curriculum only with modifications. Each indicator in the learning plan is lowered according to the abilities of students with special needs. While the implementation of individual learning programs is carried out when students are in the source class.

In the implementation of learning, inclusive education is provided with a source class in which it provides a broad and pleasant learning atmosphere, in which there are also educational toys to stimulate students who have disabilities such as Down syndrome, mental retardation and so on. The source class is a special room specifically for students with special needs that are used during guidance hours, so that they do not mix with regular classes. The goal is to provide a comfortable source class so that students with special needs can learn happily and not monotone.

Learning evaluation for inclusion education was seen from the implementation process whether there were obstacles which prevented the implementation of several programs so that re-modification was needed. The evaluation of results is shown by giving report cards or reports on student learning outcomes that are given to the Surabaya education office every month. For evaluation of student learning outcomes each semester are given report cards with two types, namely assessment report according to general students and report cards description of the results of learning assessment while in the source class. In addition, there is also an evaluation for each month by carrying out assessments, the purpose of which is to know the development of student learning there is an increase or not.

From the data obtained, the learning management of inclusive education is strongly influenced by several factors, namely: 1) school vision and mission, 2) conditions of inclusive schools, 3) conditions of inclusive schools based on the number of special needed students and their types, 4) school conditions based on the infrasturture, 5) the condition of inclusive schools based on the learning environment, and 6) the condition of the school based on the presence or absence of support.

Learning education is representative of the educator's explanation in front of the class or outside the classroom. On the other hand, learning media is located as a tool or means to achieve standards of competence and basic competencies [10]. Therefore, the preparation of learning materials should be guided by standard competencies, basic competencies, and 
graduate competency standards. The standard of graduation competence can be a reference for individual services, namely the existence of effective and efficient learning media. Effective and efficient learning in students who are fast learning, will be able to optimize their abilities by learning the material that has been prepared [11]. While the material that has been prepared for students who are slow to learn, will be able to learn the lesson repeatedly [12]. The lessons that are repeated so, can be optimized learning services for students by paying attention to teaching materials [13]. Then the instructional materials should be modified for students with special needs to be adjusted according to the needs of each individual [11].

From each of its uses, learning materials are obtained for students with special needs that are appropriate to their needs and abilities. By looking at their needs and abilities, the modification can be related to the breadth, depth and / or degree of difficulty different from the material given to students in general [14]. To students with special learning needs that can be given in the form of information, concepts, theories, subject matter, sub-subjects, etc [15]. In addition to the sub-topics there are several principles as well as ways that need to be considered by students, namely: a) based on the conditions or levels of abilities of special needs students obtained from assessment results, b) the more severe obstacles of intelligence experienced, the more extreme material modification processes and on the contrary, c) the more academic and abstract the subject matter the more the material needs to be modified [16].

In the modification of the preparation of learning materials needed flexible teaching materials, this is important to be mastered by educators because it deals with things that are specific to the impact of the special needs of students [11]. For students with special needs, the description of learning material can contain important material items that must be studied or in the form of a complete description as contained in textbooks [10]. In outline textbooks, learning material contains knowledge, skills and attitudes or values that must be learned by students with special needs. The lesson for special needs students in fulfilling the material also needs to be chosen appropriately in order to optimize the achievement of basic competency standards and graduate competency standards [17].

After fulfilling the standard of graduation competency, the steps that can be chosen in modifying the learning of inclusive education are first, identifying aspects contained in the standard of competence and original competency which become references or references. Second, identify teaching materials from the types of material. Third, choose material that is in accordance with the characteristics of the students with special needs. Fourth, namely choosing effective and efficient teaching material sources [10]. From effective and efficient teaching materials, it is necessary to identify in advance in order to facilitate educators in teaching students [17]. For the teaching of students in the implementation of learning there are obstacles to the lack of infrastructure that is not adequate, especially for children with special needs deaf, then the solution given is to provide learning first to see lip motion articulation.
Furthermore, organizing the learning of inclusive education is a way of delivering learning and managing interactions between existing learning resources in order to function optimally. To optimize, there are several things about organizing inclusive education learning that will be used in this study, namely: a) providing equipment, resources, media and instructors needed to carry out inclusive learning planning, b) developing flexible teaching materials based on competency standards, basic competencies, and competency standards passed, c) forming student services and implementing learning modifications for children with special needed, d) determining teaching materials, methods and procedures for implementing inclusive learning, e) choose, train and provide information to special companion teachers in the selection of teaching materials for the implementation of inclusive learning [10].

The implementation of inclusive education learning is an activity carried out in classroom learning for children with special needs adjusted to the planning and organization of learning in inclusive education. In learning inclusive education the things that become indicators of implementation are: a) conducting learning by paying attention to topics, material, time and space that are appropriate to the characteristics of children with special needs, b) providing learning in the form of basic skills, c) doing in an orderly manner starting from introduction, core activities and closing activities, d) Special assistant teacher often provides information about developing student learning to parents [10].

In addition to providing information to parents needed learning media used in learning activities in SDN Kalirungkut1 Surabaya, included in the full category [17]. Other complete categories include notebooks, student worksheet assignments books, laptops being one of the media used, both normal and special needs students [18]. For students with special needs, picture books are usually provided as one of the alternative media when required to take further action to the students [17]. In addition, for the students there are also media in the form of designs that have been used as a medium to explain to children with special needs when in the source class [10].

After that, evaluating the learning of inclusive education is a process or action to find the value of the expected learning according to the planning, organizing and implementation that has been applied to children with special needs. In children with special needs, several things are needed to be used as indicators in this study, including: a) monitoring of learning that has been carried out effectively, b) teachers working as special assistant teacher evaluating student learning outcomes, c) evaluating learning progress consistent, systematic and programmatic, d) evaluating work in the form of tasks, projects and / or products, portfolios, and self-assessment, e) conducting evaluations simultaneously and continuously. From continuing in inclusive education at SDN Kalirungkut-1 Surabaya, it is held regularly to assess the learning outcomes of students with special needs, carried out according to the test schedule and the questions given have been made separately by the special assistant teacher. Special companion teachers make their own questions with the aim that there is an evaluation of the results of this assessment to find out how 
successful the learning is in supporting the development of students with special needs.

\section{CONCLUSION}

The conclusion that can be taken regarding this research are:

1) Planning in curriculum management and learning of inclusive education in children with special needs in SDN Kalirungkut 1 Surabaya is started by making syllabus planning, and Individual Learning Program that are tailored to the needs of each student with special needs to be carried out in the process regular class learning.

2) Organizing the curriculum and learning about inclusive education in children with special needs begins with grouping first in the division of tasks for implementing learning planning in the regular classroom and in the learning resource class (inclusion). Executors in the field include homeroom teachers, study teachers and special assistant teachers who are in charge of assisting students with special needs.

3) The implementation of the curriculum and learning for the learning model of each class has a difference, but it still leads to acquisitions of lesson plan and individual learning program that have been prepared previously. Every inclusive education program has a special service program for each student with special needs, each learning process is always integrated with aspects of student development and some of them maximize their talents, interests of students with special needs. In accordance with Tomlison (2010) bring differentiated learning can be in the form of context or content, processes and products that are adapted to the conditions of students and school conditions. Similarly, in the implementation of learning it is necessary to pay attention to the standard processes used.

4) Evaluation of the implementation of curriculums and the study of inclusive education for student participants with special needs is done by providing a review of the implementation process that has been running and providing evaluation of the results of assessment of student learning. Furthermore, building perceptions, awareness, and interactive efforts of students, policy makers, and the quiet community in implementing inclusive education is not easy. Changing the paradigm that has developed in the community about the existence of children with special needs who are considered to be other requires a comprehensive solution. In this case, the role of education must be a driving force in building awareness of inclusion in the community.

Therefore, through the findings we suggest:

1) The implementation of inclusive education must be socialized massively to students, teachers, policy makers, and the community. This is expected so that they do not feel alienation from the noble values of humanity. Education has a very strategic position in society, therefore, it is expected that the process of education can play an important role as a social transformation in building social friendly civilizations.

2) Central and regional government regulations that have been issued must be able to become a reference or guideline rather than the implementation of the current implementation of inclusive education. Therefore, it should be appropriate to build a socially friendly civilization starting with building awareness from generations of creators and future historical actors to recognize the values of humanism in the education process early on.

\section{ACKNOWLEDGEMENT}

The author would like to thank all those who contributed to the making of this article, especially to the officials of the education management program Universitas Negeri Surabaya and principals and special companion teachers at SDN Kalirungkut-1 Surabaya. This article only reflects the views of the author based on the research that has been carried out in inclusive education.

\section{REFERENCES}

[1] Latief, "Pendidikan Inklusi Masih Banyak Kendala," kompas.com, p. 1, 04-Nov-2009.

[2] A. M. Jazeel and A. R. Saravanakumar, "Challenges for Improving Quality in Education at Primary and Secondary schools in India and Sri Lanka," J. Soc. Welf. Manag., vol. 9, no. 2, 2017.

[3] Bernas, "Surabaya Pioner Pendidikan ABK: Pendidikan inklusi dipandang istimewa di Surabaya sejak Tri Risma menjabat sebagai Wali Kota Surabaya.," bernas.id, p. 1, 11-Feb-2018.

[4] T. Shakespeare and N. Watson, "The social model of disability: an outdated ideology?," in Exploring theories and expanding methodologies: Where we are and where we need to go, Emerald Group Publishing Limited, 2001, pp. 9-28.

[5] C. C. Cavallaro and M. Haney, Preschool Inclusion. ERIC, 1999.

[6] G. L. Porter, "Disability and inclusive education," in Inter-American Development Bank Seminar on Inclusion and Disability Santiago, Chile, 2001.

[7] Y. Riyanto, Metodologi Penelitian Pendidikan, Suatu Tinjauan Dasar. Surabaya: SIC, 2016.

[8] L. J. Moleong, "Metodologi penelitian kualitatif (Revisi)," Bandung PT remaja rosdakarya, 2017.

[9] S. Tarsito, "Metode Penelitian Kuantitatif, Kualitatif dan R\&D," Alf. Bandung, 2014.

[10] B. Delphie, "Pembelajaran Anak Berkebutuhan Khusus dalam Setting Pendidikan Inklusi Yogyakarta: PT,” Intan Sejati Klaten, 2009.

[11] M. Poni, "Inclusive Education for Children with Special Educational Needs in Albania," Tirana, 2017.

[12] S. P. Robbins and M. Coulter, "Management. Terj," Bob Sabran dan Devri Burn. Puter. Jakarta Penerbit Erlangga, 2010.

[13] H. Jackman, N. Beaver, and S. Wyatt, Early education curriculum: A child's connection to the world. Cengage Learning, 2014.

[14] S. Vakil, E. Welton, B. O’Connor, and L. S. Kline, "Inclusion means everyone! The role of the early childhood educator when including young children with autism in the classroom," Early Child. Educ. J., vol. 36 , no. 4, p. 321, 2009.

[15] R. P. Brinker, "Interactions between severely mentally retarded students and other students in integrated and segregated public school settings.," Am. J. Ment. Defic., 1985.

[16] J. A. F. Stoner and R. E. Freeman, "Manajemen Jilid I (Terjemahan)," Ed. ke-5. Intermedia, Jakarta. Lampiran, vol. 1, pp. 2003-2007, 1994.

[17] T. Vrasmas, "Curriculum for Children with Disabilities in Inclusive Education. A Literature Review," Procedia-Social Behav. Sci., vol. 127, pp. 336-341, 2014.

[18] I. M. Evans, C. L. Salisbury, M. M. Palombaro, J. Berryman, and T. M. Hollowood, "Peer interactions and social acceptance of elementary-age children with severe disabilities in an inclusive school," J. Assoc. Pers. with Sev. Handicap., vol. 17, no. 4, pp. 205-212, 1992. 